\title{
Job Security and Due Process: Monitoring Administrative Discretion Through a Reasons Requirement
}

\author{
Robert L. Rabin†
}

In determining the procedural safeguards to be afforded to property interests under the due process clauses of the Constitution, the Supreme Court has assumed that the principal value at stake is the interest in an accurate decision, and that this interest can be protected only by requiring some form of evidentiary hearing. Focusing on the job security cases, in particular the recent decision in Bishop v. Wood, Professor Rabin contends that these assumptions have resulted in setting too high a threshold for the recognition of property rights and in an unwarranted deference to state law in determining the scope of constitutionally protected property. He argues that in addition to the interest in an accurate decision, courts should attend to the interest in a reasoned explanation for the termination of employment, an interest that can be secured through a modest form of judicial review without requiring a costly evidentiary hearing.

The need for security of interest in government largess was sharply underscored two decades ago in the years of national trauma we now refer to as the McCarthy era. The mid-1950s witnessed the acceleration of two phenomena that have redefined the individual's relationship to the state: the ubiquitous growth of the public sector and the consequent proliferation of relationships binding the citizen to the state. ${ }^{1}$ Charles Reich expressed concern with these developments when he wrote of an emergent "new property"-a conception of property that both delineated the various forms of government largess distributed in a welfare state and prescribed the need for safeguards against government officials abusing their power by en-

$\dagger$ Professor of Law, Stanford University. An earlier draft was read by Professors Paul Brest, Owen Fiss, and Tom Grey. I benefited greatly from their suggestions, as well as our many earlier discussions of the issues addressed in this article.

1 The Civil Service reform movement may have been partially responsive to similar disquietude about security of interest, but that movement was primarily a product of concern about the spoils system and its effects on the quality of government service. For a discussion of the Civil Service reform movement, see D. Rosenbloom, Federal Service and The Constifution 70-93 (1971); Frug, Does the Constitution Prevent the Discharge of Civil Service Employees? 124 U. PA. L. REv. 942, 954-61 (1976). 
croaching upon the autonomy of recipients. ${ }^{2}$

A particularly distressing feature of the McCarthy period was the runaway impulse of government to demand loyalty-more seriously, to punish those having the temerity to maintain idiosyncratic beliefs. It was concern for the dissenter and the eccentric, whether in the political arena or in matters of life-style, that informed the commentary of the early 1960s in the critical backlash against the preceding years of state-coerced conformity. ${ }^{3}$ Given the massive presence of the federal and state governments in allocating jobs, licenses, housing and welfare benefits, the courts were inevitably confronted with a wide range of property claims arising out of the administrative termination of government largess. ${ }^{4}$

Assumptions that had been treated as received wisdom were called into question-most critically, the assumption that recipients of government "benefits" held only a "privilege" subject to whatever limitations the government saw fit to attach. ${ }^{5}$ Once it was conceded that the recipient of largess was entitled to some degree of security, it followed that official conduct had to be channeled through regularized procedures that insured fair treatment. With a heightened sense of exigency, the administrative process was measured against constitutional norms of procedural due process, and concern about linking changes of status to the right to a hearing became paramount. ${ }^{6}$ The leading case of Goldberg $v$. Kelly, ${ }^{7}$ involv-

2 See generally Reich, The New Property, 73 Yale L. J. 733 (1964).

3 See, e.g., id.; Linde, Justice Douglas on Freedom in the Welfare State-Constitutional Rights in the Public Sector, 39 WASH. U.L.Q. 4 (1964). An early exposition, focusing on the cases arising out of the governmental preoccupation with loyalty during the 1950 s, is Davis, The Requirement of a Trial-Type Hearing, 70 HARv. L. REv. 193 (1956).

- A number of these cases are discussed in Reich, supra note 2. He makes Flemming v. Nestor, 363 U.S. 603 (1960), the cornerstone of his analysis. Nestor's wife had her Social Security benefits cut off after he was deported for past membership in the Communist Party. A divided Court upheld the statutory provisions allowing the retroactive termination of benefits in the face of a constitutional attack on due process grounds. Because old age benefits were involved and the termination was for "deviant" political beliefs, Reich regarded the case as a prototypical instance of the power of the state to coerce the individual into conformist behavior.

In the area of public employment job security, which will be the primary focus of this article, a number of key cases were decided. See, e.g., Cafeteria \& Restaurant Workers Local 473 v. McElroy, 367 U.S. 886 (1961); In re Anastopolo, 366 U.S. 82 (1961); Konigsberg v. State Bar, 366 U.S. 36 (1961); Greene v. McElroy, 360 U.S. 474 (1959); Schware v. Board of Bar Examiners, 353 U.S. 232 (1957) (involving occupational licensing standards); Bailey v. Richardson, 182 F.2d 46 (D.C. Cir. 1950), aff'd by an equally divided court, 341 U.S. 918 (1951).

${ }^{5}$ For a detailed treatment of the rights-privilege distinction, see Van Alstyne, The Demise of the Right-Privilege Distinction in Constitutional Law, 81 HaRv. L. REv. 1439 (1968); K. Davis, Administrative Law Treatise $\$$ 7.11-.13 (1958 \& Supp. 1970).

- The job security cases cited in note 4 supra are instructive. The majority opinion of the court of appeals in Bailey v. Richardson, 182 F.2d 46 (D.C. Cir. 1950), aff'd by an equally 
ing the right of recipients of Aid to Families with Dependent Children (AFDC) to an evidentiary hearing prior to the termination of benefits, presaged claims for judicial recognition of entitlements to a wide variety of forms of government largess. ${ }^{8}$

This article will be primarily concerned with a single important line of cases in which the Supreme Court has been notably unable to develop a satisfying approach for resolving claims to security of interest in government largess. I will focus on the job retention cases, using the recent decision in Bishop $v$. Wood ${ }^{9}$ as the pivot for the analysis. While my main concern will be with the employment cases, I have a somewhat broader design in mind. Since the tension between individual security and bureaucratic efficiency underlying the job retention cases is an identifiable theme in virtually every entitlement controversy, I view the Court's inability to devise a satisfying framework for analysis in the employment cases as symptomatic of a general failure to deal with entitlements and related procedural due process claims in sufficiently flexible terms. ${ }^{10}$ Thus,

divided court, 341 U.S. 918 (1958), rests on the premise that public employment is a privilege and not a right-making due process inapplicable. A decade later, in Cafeteria \& Restaurant Workers Local $473 v$. McElroy, the Court conceded that procedural due process guarantees are triggered by government employment, although it ruled they were not violated in the immediate case. The stage had been set for this new conception of government employment in the preceding case of Greene v. McElroy, 360 U.S. 474 (1969), where the Court read the statute broadly to require adjudicatory safeguards, and thereby avoided what it regarded as possible due process concerns raised by a narrower construction. See generally Van Alstyne, supra note 5 , at 1461 .

7397 U.S. 254 (1970).

* Goldberg was not, of course, the first case to recognize the importance of security of interest in government largess. The traditional distinction between rights and privileges assumed that some kinds of interests-"rights"-were entitled to procedural due process safeguards. See authorities cited in note 5 supra. But from a historical perspective it is clear that the case law of the 1970s rejecting the rights-privileges approach dates from and is based upon the Goldberg recognition of a "property" interest in welfare benefits. See generally Friendly, "Some Kind of Hearing," 123 U. PA. L. REv. 1267 (1975).

- 96 S. Ct. 2074 (1976).

to Throughout this article, "entitlements" and "property" interests will be referred to interchangeably. I will not attempt to deal with the "liberty" interest that is regularly entertained, and just as regularly put to rest, in each of the recent Supreme Court decisions on job security. See Bishop v. Wood, 96 S. Ct. 2074, 2079-80 (1976); Arnett v. Kennedy, 416 U.S. 134, 156-58 (1974); Board of Regents v. Roth, 408 U.S. 564, 572-75 (1972); Perry v. Sindermann, 408 U.S. 593, 599 (1972).

The Court's analysis of the liberty interest is generally framed in terms of whether the ground for dismissal of the employee is sufficiently stigmatic to hamper seriously the employee's opportunity to find similar work elsewhere. The compartmentalization of "liberty" and "property" claims in job security cases is open to question, as is the Court's narrow view of what constitutes a "stigma." But an adequate treatment of the issue would extend far beyond the scope of the present article.

The Court's general unwillingness to interpret damage to reputation as a violation of a "liberty" interest protected by the fifth and fourteenth amendments is vividly illustrated by 
in offering a new approach to the resolution of job security issues it will be necessary to survey analogous lines of conflict.

After examining the approach taken by the Court in linking a theory of entitlements to procedural due process, I will explore the purposes that such a linkage is intended to serve. I will argue that the failure to identify all of the values protected by due process has led to an inadequate conception of entitlements and an insufficient range of due process safeguards. In particular, I will propose a more expansive approach that stresses the singular importance of receiving an adequate explanation for adverse treatment whenever substantial individual interests are at stake. I will then attempt to demonstrate concretely, through the job security cases, how this approach would be utilized.

\section{Entitlement Theory and Employment Security: The Dialogue in GoldBerg v. Kelly and Its Progeny}

Goldberg $v$. Kelly ${ }^{11}$ established the terms of the dialogue in procedural due process cases ranging from revocation of parole to suspension of drivers' licenses. ${ }^{12}$ In holding that AFDC recipients were entitled to a pretermination evidentiary hearing, the Court first noted that welfare benefits were "a matter of statutory entitlement," adding in a footnote that such benefits might realistically be viewed as a form of property.$^{13}$ Assuming, then, that due process safeguards applied, the Court went on to assert that "[ $t]$ he extent to which procedural due process must be afforded the recipient is influenced by the extent to which he may be 'condemned to suffer grievous loss,' . . . and depends upon whether the recipient's interest in avoiding that loss outweighs the governmental interest in

Paul v. Davis, 96 S. Ct. 1155 (1976), a recent decision rejecting a claimed infringement of due process where the claimant had been designated an "active shoplifter," despite the absence of a criminal conviction, in a flyer distributed by the local police. The Court refused to "single out reputation as a candidate for special protection over and above other interests that may be protected by state law." Id. at 1160 .

" 397 U.S. 254 (1970).

12 See, e.g., Morrissey v. Brewer, 408 U.S. 471 (1972); Bell v. Burson, 402 U.S. 535 (1971); cases discussed in text and notes at notes 15-28 infra. Both the scope of the entitlements and the applicability of the due process safeguards required by Goldberg v. Kelly, 397 U.S. 254 (1970), remain the subject of debate within the social welfare area itself. See, e.g., Mathews v. Eldridge, 424 U.S. 319 (1976).

13397 U.S. at 262 n.8. The footnote continues with a lengthy quotation from Reich, Individual Rights and Social Welfare: The Emerging Legal Issues, 74 YALE L.J. 1245, 1255 (1965), which emphasizes the importance of establishing security in entitlements-the thesis Reich had developed in The New Property, supra note 2. 
summary adjudication."14 Applying that balancing test to the AFDC recipient, the Court found that the costs likely to be incurred by such an individual upon losing the minimal level of sustenance provided under the program outweighed the additional expense that would be imposed on the government by requiring it to provide the added procedural safeguard of a pretermination evidentiary hearing.

The issue of entitlement to job security came to the Supreme Court within two years of Goldberg in a pair of key cases, Board of Regents $v$. Roth ${ }^{15}$ and Perry $v$. Sindermann. ${ }^{16}$ Factual distinctions between the two cases gave the Court the opportunity to refine the entitlement, or property, conception suggested in Goldberg. Roth had been hired as a nontenured assistant professor at Wisconsin State University at Oshkosh on a one-year contract. During the year, he was notified that his contract would not be renewed. While Wisconsin statutes provided various protections for state university faculty members with four or more years of service, a less experienced teacher was entitled to nothing-neither a hearing, a discussion, nor even a good reason for termination.

Similarly, the Texas state system in which Sindermann taught provided him with no procedural safeguards against summary dismissal; and he was fired without either a hearing or an official explanation. Unlike Roth, however, Sindermann had been teaching in the Texas state college system for ten years. Even more significantly, no one in the system had formal tenure; instead, the administration had published rules and guidelines indicating that after a "probationary" period of seven years faculty members should regard their positions as "permanent."

Seizing upon this evidence of a de facto tenure system, the Court distinguished Sindermann's situation from that of Roth. The Court reasoned that Sindermann's interest had ripened into an expectation of continued employment-a "property" interest in his job which could be terminated only for cause, determined by appropriate procedures. Roth, on the other hand, had by the terms of his appointment "secured absolutely no interest in reemployment"; in other words, he had no property interest that required procedural safeguards. ${ }^{17}$

14397 U.S. at 262-63, citing Joint Anti-Fascist Refugee Comm. v. McGrath, 341 U.S. 123, 168 (1951) (Frankfurter, J., concurring).

is 408 U.S. 564 (1972).

16408 U.S. 593 (1972).

17408 U.S. at 578. 
Taken together, Roth and Sindermann can be read to suggest three distinct levels of analysis. At one level are cases involving "property" interests where, as in Goldberg, there must be an administrative hearing prior to termination. At a second level are cases where there is no established property interest, but the recipient claims an abridgement of his right to engage in a constitutionally protected activity, such as the right of free speech. ${ }^{18}$ In such a case, no administrative hearing is required, but there must be a hearing somewhere before the recipient's interest in maintaining his job can be denied. ${ }^{19}$ Thus, in Roth, the Court remanded the case to the district court for a judicial determination of whether the petitioner had been terminated for engaging in an activity protected by the first amendment. Finally, at a third level are cases where the petitioner is unable to rely on either a property interest or a protected activity-the case, presumably, if Roth had been terminated for being a nasty colleague or an incompetent teacher. In such situations, it is not simply that the administration is justified in failing to rehire; the teacher is not even entitled to an explanation of the reasons for nonrenewal.

In Roth and Sindermann the notion of a property interest in largess had moved from the footnotes in Goldberg to an established "test" for measuring the security of interests. ${ }^{20}$ Six justices reaf-

ix Both the infringement of property interests and the abridgement of first amendment rights are actionable under 42 U.S.C. $\$ 1983$ (1970):

Every person who, under color of any statute, ordinance, regulation, custom, or usage, of any State or Territory, subjects, or causes to be subjected, any citizen of the United States or other person within the jurisdiction thereof to the deprivation of any rights, privileges, or immunities secured by the Constitution and laws, shall be liable to the party injured in an action at law, suit in equity, or other proper proceeding for redress.

The "rights . . . secured by the Constitution" in $\$ 1983$ include activities protected by the first amendment and property interests protected by the due process clause of the fourteenth amendment. Whether a constitutional right to a hearing in some forum would exist in the absence of $\S 1983$ is a question the Court has not confronted.

" In Board of Regents v. Roth, 408 U.S. 564 (1972), the Court was careful to point out that the district court had stayed proceedings on Roth's allegation that he had been terminated for engaging in activity protected by the first amendment. Id. at $568 \mathrm{n} .5$. Thus, there had been no evidentiary determination of that issue. The Court explicitly considered requiring a pretermination evidentiary hearing as a deterrent to potential infringement of protected rights. Distinguishing cases where such a requirement was imposed, the Court reasoned that

[in Roth's] case . . . the State has not directly impinged upon interests in free speech or free press in any way comparable to a seizure of books or an injunction against meetings. Whatever may be a teacher's rights of free speech, the interest in holding a teaching job at a state university, simpliciter, is not itself a free speech interest.

Id. at 575 n.14. Thus, while acknowledging that "the right to some kind of prior hearing is paramount," id. at 569-70, the Court did not require a pretermination administrative hearing.

20 See, e.g., Board of Regents v. Roth, 408 U.S. 564, $577-78$ (1972); Perry v. Sindermann, 408 U.S. 593, 599-602 (1972). 
firmed the approach taken in these cases in the next job security case to come before the Court, Arnett $v$. Kennedy. ${ }^{21}$ Kennedy held a nonprobationary position as a field representative in a regional OEO office. In this position, he was afforded the job security established for federal civil servants by the Lloyd-LaFollette Act: he was entitled, in "such cases as will promote the efficiency of the service," to notice, an opportunity to comment, and a written statement of reasons for dismissal prior to removal. ${ }^{22}$ By regulation, the agency had established additional safeguards, including the right to a posttermination evidentiary hearing. Nevertheless, when Kennedy was dismissed for allegedly making false accusations of corrupt practices by his superior, he appealed on the ground that, as in Goldberg, he was entitled to a pretermination evidentiary hearing.

The six justices who adhered to the Goldberg approach, as refined in Roth and Sindermann, proceeded to determine that Kennedy had the requisite security of interest in retaining his job to trigger procedural due process protection. Where the six Goldberg adherents parted company was on the application of the balancing test to the immediate case: three justices believed that the entitlement at stake was sufficiently weighty to require a pretermination evidentiary hearing ${ }^{23}$ while the other three accepted the more modest safeguards provided by the statute and regulations. ${ }^{24}$

But a strongly dissonant chord was struck by Justice Rehnquist's plurality opinion. ${ }^{25}$ In his view, the Lloyd-LaFollette Act could not be "parsed as discretely" as the concurring and dissenting justices had argued. Rather, he countered, "[W] of a substantive right is inextricably intertwined with the limitations on the procedures which are to be employed in determining that right, a litigant in the position of [the plaintiff] must take the bitter with the sweet." ${ }^{26}$ In other words, rules structuring the grant of government largess cannot be appropriately contained within compartments labelled "substantive" and "procedural." Rather, the procedural safeguards in the Lloyd-LaFollette Act qualified the substantive right-were integral to the definition of the bargain

21416 U.S. 134 (1974).

${ }_{22} 5$ U.S.C. $\$ \S 7501$ (a), (b) (1970). The Act is discussed in detail in Frug, supra note 1.

${ }^{23} 416$ U.S. at 206-31 (Marshall, Douglas \& Brennan, JJ., dissenting).

24416 U.S. at 164-71 (Powell \& Blackmun, JJ., concurring). Justice White, in a separate concurrence, took an intermediate position. While he did not regard a pretermination evidentiary hearing as essential, he did think that the existing notice-and-comment procedures were inadequate in Kennedy's case because of the bias of the designated hearing officer-the very supervisor Kennedy had charged with corrupt practices. Id. at 196-99.

${ }^{25}$ Chief Justice Burger and Justice Stewart joined in Justice Rehnquist's opinion.

${ }^{28} 416$ U.S. at 153-54. 
struck between employee and employer-and consequently established the parameters of Kennedy's entitlement to job security. ${ }^{27}$

Whatever its persuasiveness, the plurality view expressed by Justice Rehnquist marked a distinct departure from the Goldberg approach to defining property interests. ${ }^{28}$ If in Goldberg the statutory scheme had established the limits of the security of interest AFDC recipients could claim, then Goldberg was incorrectly decided, since the very issue in the case was whether recipients were entitled to a pretermination evidentiary hearing in addition to the statutory procedures. Similarly, in Sindermann, the Texas administrative rules and guidelines said absolutely nothing about procedural safeguards. If, following Justice Rehnquist's approach, the "for cause" standard gleaned by the Court from the policy pronouncements of Texas higher education officials had been qualified by the state's evident unwillingness to establish procedural requisites, the state officials would have been granted absolute discretion in administering their de facto tenure system..$^{29}$

What Justice Rehnquist's position demonstrated, then, was an erosion of support for the activist posture taken in Goldberg and its progeny. Those cases propound, in the name of constitutional due process, the necessity for an independent judicial determination whether a state-established security of interest amounts to a "property" interest that carries with it a guarantee of at least minimal procedural safeguards. By contrast, the positivist approach ${ }^{30}$

${ }^{27}$ For a thoughtful analysis, see Grey, Procedural Fairness and Substantive Rights, in Nomos XVIII: DuE Process 182 (J. Pennock \& J. Chapman eds. 1977). The author suggests that one must confront "the paradox presented by constitutional indifference to the substantive content and indeed to the very existence of benefit programs, combined with deep constitutional concern for the procedures through which those programs are administered once established." He argues that the resolution of the problem requires a resort to categories resembling the traditional distinction between rights and privileges-a distinction based on the recognition that some kinds of claims against the state are intrinsically more valuable than others, and consequently require more substantial procedural protection. See note 95 infra.

2* Chief Justice Burger, separately concurring in Roth and Sindermann, had indicated that he regarded the definition of the "property" interests subject to due process safeguards to be exclusively a matter of state law. Perry v. Sindermann, 408 U.S. 593, 603-04 (1972) (concurring opinion). But he did not take the significant additional step of treating the absence of state-created procedural safeguards as integral to the initial definition of the property interest. Earlier Justice Black, dissenting in Goldberg v. Kelly, 397 U.S. 254, 275 (1970), had argued that "the government's promise of charity" was made on the legislature's own terms. But his argument was addressed specifically to welfare benefits under the AFDC program.

20 But see Frug, supra note 1, at 982-83 (suggesting a narrower reading that would limit Justice Rehnquist's insistence on synchronizing the substantive and procedural provisions to construction of the Lloyd-LaFollette Act).

${ }^{30}$ See note 44 infra. 
employed by Justice Rehnquist would eschew independent judicial determination of the applicability of due process guarantees by deferring to the statutes, regulations, and case law establishing the limits of property interests. With respect to federal job security, for example, the positivist approach entitles one to only that process that has been authoritatively promised by official statute and regulation.

Thus, the dialogue in Arnett reveals clear lines of disagreement, not simply about the "value" to be attached to job security, but more fundamentally over the very propriety of an independent judicial determination of property interests in government employment, or, more broadly, in the entire range of governmental largess. Those lines of disagreement, rather clearly demarcated in Arnett, became hopelessly confused in the most recent job retention case, Bishop $v$. Wood. ${ }^{31}$ At the root of the confusion is a conceptual weakness that traces back at least to Roth and Sindermann; the identification of this shortcoming may point toward a more satisfying methodology for resolving these cases.

\section{From Colloquy to Confusion: Bishop v. Wood}

Carl Bishop had served on the Marion, North Carolina police force for almost three years when he was discharged on March 31, 1972. The City Manager dismissed him on the recommendation of W. H. Wood, Chief of Police, who claimed that Bishop had failed to discharge his duties properly. More specifically, Bishop was accused of engaging in high speed auto chases outside the city limits, failing to check business establishments and respond to routine patrol calls in a satisfactory fashion, missing a number of training sessions, and damaging the morale of the force. Bishop appears to have been aware of the Chief's displeasure, and he was dismissed at a meeting with the City Manager at which the Chief was present; but he uncontestably did not receive an evidentiary hearing on the propriety of his dismissal. He argued that the failure to provide such a hearing deprived him of procedural due process.

The City Manager acted pursuant to a local ordinance, applicable to public employees with service beyond a six month probationary period, that read as follows:

Dismissal. A permanent employee whose work is not satisfactory over a period of time shall be notified in what way his work

31 96 S. Ct. 2074 (1976), aff'g 498 F.2d 1341 (4th Cir. 1974), aff'g per curiam 377 F. Supp. 501 (W.D.N.C. 1973). 
is deficient and what he must do if his work is to be satisfactory. If a permanent employee fails to perform work up to the standard of the classification held, or continues to be negligent, inefficient, or unfit to perform his duties, he may be dismissed by the City Manager. Any discharged employee shall be given written notice of his discharge setting forth the effective date and reasons for his discharge if he shall request such a notice. ${ }^{32}$

The district court granted the defendants' motion for summary judgment, holding that the procedural safeguards in the ordinance had been respected, and that, since his employment was "terminable at will" under North Carolina law, Bishop was entitled to nothing more. ${ }^{33} \mathrm{~A}$ three-judge panel of the Fourth Circuit Court of Appeals affirmed the district court with one judge dissenting, ${ }^{34}$ and on rehearing en banc was equally divided in reaffirming. ${ }^{35}$ Again upholding the trial court by the narrowest of margins, the Supreme Court affirmed with four justices dissenting. ${ }^{36}$

Justice Stevens, writing for the majority of the Court, held that the district court's construction of the ordinance as creating a contract terminable at will, subject only to whatever procedural safeguards the state established, was a "tenable" reading of North Carolina law; as such, he reasoned, it was binding on the Court since the property rights-triggering requirements of procedural due process-were to be defined by reference to state law. Both of these propositions require careful analysis: the reading of North Carolina law is dubious and undermines the authority of the opinion; but more critically, the deference to state law in defining the substantive property interest suggests such a sharp departure from the entitlement theory developed in Goldberg and its progeny as to require a reassessment of the underlying bases for protecting security of interest in largess. ${ }^{37}$

Consider, first, the district court's reading of North Carolina law. The district judge relied on a single case, Still $v$. Lance, ${ }^{38}$ to support the proposition that the Marion ordinance created a

32 Personnel Ordinance of Marion, N.C., art. II, $\S 6$, cited in Bishop v. Wood, 96 S. Ct. 2074, 2077 n.5 (1976).

33 Bishop v. Wood, 377 F. Supp. 501 (W.D.N.C. 1973).

ss Bishop v. Wood, 498 F.2d 1341 (4th Cir. 1974) (per curiam).

${ }^{35}$ See 96 S. Ct. at 2077 n.35.

3t The dissenters were Justices Brennan, Marshall, White, and Blackmun.

${ }^{37}$ I use the term "deference" in its strongest sense. The majority treated state law as determinative in establishing property interests, not simply as entitled to some degree of respect.

3* 279 N.C. 254,182 S.E.2d 403 (1971). 
terminable-at-will employment contract subject to whatever procedural safeguards, if any, the state chose to afford. ${ }^{39}$ That case involved a high school teacher who alleged that she was not reappointed because the board of education assumed she would be looking elsewhere for a position during the succeeding year since her husband's teaching job had similarly been terminated. The state court's decision that she was entitled to no hearing on the question of reappointment focused entirely on a statute that rather clearly appears to regard teaching contracts as extending from year to year. ${ }^{40}$ Moreover, the state court read the statute in light of its own view of the realities of a secondary education system:

The nature of school operations is such that, in the absence of evidence of a contrary intent, a contract for the employment of a school teacher is presumed to be intended by the parties to continue to the end of the school year and not to be terminable by either party prior to that time without cause and without the consent of the other party. ${ }^{41}$

The status of policemen hired subject to the Marion ordinance is not illuminated by reference to the statutory framework of the state educational system. ${ }^{42}$ The important question of state law in Bishop was whether the Marion ordinance gave a public employee a contract terminable at will after a six month probationary period had expired. Still $v$. Lance is unresponsive to this question since the

39 The Court begins with an expression of deference to the views of the district judge, who had "practiced law [in North Carolina] for many years." 96 S. Ct. at 2078. No correlative head count of the expertise on the equally divided Fourth Circuit is offered. Since Still v. Lance, 279 N.C. 254,182 S.E. 2 d 403 (1971), presumably can be read with equal facility whether or not one is an experienced North Carolina practitioner, it is hard to take seriously the Court's expression of deference to the lower court.

sa The North Carolina statute provides in pertinent part:

All contracts now or hereafter entered into between a county or city board of education and a teacher, principal, or other professional employee shall continue from year to year unless terminated as hereinafter set forth. When it shall have been determined by a county or city board of education that an employee is not to be retained for the next succeeding school year it shall be the duty of the county or city superintendent to notify the employee, by registered letter deposited in mails addressed to last known address or business address of employee prior to the close of the school year, of the termination of his contract.

Act of April 24, 1967, 1967 N.C. Sess. Laws ch. 223, § 1 (repealed 1971).

$" 279$ N.C. at 259,182 S.E.2d at 407.

12 If Still v. Lance, 279 N.C. 254,182 S.E.2d 403 (1971), is analogous to any of the cases discussed earlier, it is Board of Regents v. Roth, 408 U.S. 564 (1972)-where the teacher was also hired on a one-year contractual basis-rather than Bishop. Even in a term contract case, however, if the teacher has a tenure track position it is doubtful that the agreement implies a right to dismiss for any reason, including reasons unrelated to institutional needs. This point is developed more fully in text at notes 91-94 infra. 
court treated teachers' positions as renewable one-year agreements. Furthermore, the Marion ordinance includes a provision which appears to limit dismissal to "cause"-a standard that has no counterpart in the educational proviso construed in Still.

The Court's superficial analysis of North Carolina law is far less important than its decision to defer to state law as the definitive source of required procedural safeguards. Suppose that Still $v$. Lance could be fairly read as establishing that "permanent" public employment is terminable at will or on whatever procedural terms the state provides, so long as no explicit term of tenure has been created. On that dubious reading of North Carolina law, which the majority seems to adopt, we confront the real significance of the Bishop decision. For the Court ruled that "the ultimate control of state personnel relationships is, and will remain, with the States; they may grant or withhold tenure at their unfettered discretion." 43 Hence, once the Court accepted the expansive reading of Still $v$. Lance, the absence of any explicit tenure guarantee in the Marion ordinance left Bishop and other employees vulnerable to the least charitable reading of the statutory provision.

The positivist underpinning of the majority's position is still more clearly revealed if we assume that Still $v$. Lance has no bearing on the interpretation of local law. ${ }^{44}$ The ordinance may have been tenably construed, the Court says, "as granting no right to continued employment but merely conditioning an employee's removal on compliance with specified procedures." ${ }^{45}$ Since the states-it bears repeating-"may grant or withhold tenure at their unfettered discretion," a positivist analysis of Bishop's security of interest reveals that he is entitled only to the narrowest possible reading of what the ordinance has provided him: in this case, an unreviewable determination of whether his job performance has been substandard. ${ }^{46}$

is 96 S. Ct. at 2080 n.14.

" By "positivist approach" I refer to a conception of legal interests-in this case "property" interests-that is based exclusively on the authority of state legislative, regulatory, and judicial pronouncements, rather than on constitutional sources. In the context of defining federally created "property" interests, as in Arnett v. Kennedy, 416 U.S. 134 (1974), the positivist approach would rely solely on federal statutes, regulations, and judicial constructions thereof. In each case there is no independent determination of constitutional due process requirements.

is $96 \mathrm{~S}$. Ct. at 2078.

"While the ordinance entitled Bishop to "written notice of reasons" for his dismissal, see text at note 32 supra, the majority opinion treats this provision as merely a formal requirement, not subject to substantive review-the notice could presumably say anything or, in substance, nothing at all. This cavalier treatment will be reconsidered in much greater detail in text at section VI infra. 
Near the end of the majority opinion, the Court refers to a dissenting view, "Mr. Justice Brennan's remarkably innovative suggestion that we develop a federal common law of property rights." $" 17$ This comment, it seems to me, goes to the heart of the matter. For, if the cases beginning with Goldberg were not developing "a federal common law of property rights" it is impossible to comprehend the decisions. One would have thought that the dialogue sparked by Justice Rehnquist in Arnett made that clear. ${ }^{48}$ But the majority's attempt to reconcile its positivist approach in Bishop with the views of the majority that rejected Justice Rehnquist's position in Arnett raises the question whether the Court recognizes the full thrust of its more recent decision:

In [Arnett] the Court concluded that because the employee could only be discharged for cause, he had a property interest which was entitled to constitutional protection. In [Bishop], a holding that as a matter of state law the employee "held his position at the will and pleasure of the city" necessarily establishes that he had no property interest. ${ }^{49}$

This attempted reconciliation completely misses the point that it is not a question of which label- "property" or "no property"-one attaches to the status of the job interest, but of who does the labeling. ${ }^{50}$ A majority in Arnett most assuredly did believe that the property interest in a federal civil service job was to be defined by an independent judicial determination, from a constitutional due process perspective, of an employee's reasonable expectations to security of interest in his job.1

1796 S. Ct. at 2080 n.14.

10 See text at notes 25-31 supra.

1996 S. Ct. at 2078 n.8.

so The majority's attempt to reconcile Bishop with Arnett also indicates that it was not establishing a distinction between federal and state-created interests that would grant the federal courts authority to define property rights for due process purposes in the former sphere but not in the latter.

st See note 28 supra. For a criticism of the two-stage approach to defining procedural protection for property interests, see Tushnet, The Newer Property: Suggestion for the Revival of Substantive Due Process, 1975 Sup. CT. REv. 261. Tushnet argues for an independent constitutional determination of the due process safeguards for property interests through a limited revival of substantive due process. I think that a majority of the Court has, in fact, been relying on substantive due process, although not clearly articulated as such, in determining entitlements to security of interest. The Court's approach remains, however, a twostage analysis in the important sense that the existence of an entitlement, whether we call it "property" or a "substantive due process interest," is a separate question from the extent of procedural protection granted. 
The point is perhaps most clearly made by reference to the earlier job security cases based, like Bishop, on state employment relationships. Justice Stevens makes much of the statement in Roth that property interests are "defined by existing rules or understandings that stem from an independent source such as state law."52 But one must underscore "such as," and read it in conjunction with the immediately preceding language in Roth asserting that "[i]t is a purpose of the ancient institution of property to protect those claims upon which people rely in their daily lives, reliance that must not be arbitrarily undermined." ${ }^{53}$ Most critically, Roth must be read as a companion case to Sindermann where, again, no procedural safeguards were provided by the state. Yet, the Court refused to cut back the implied "for cause" standard in the Texas rules and regulations through synchronization with the correlative absence of procedural protection afforded by the state. Instead, as in Goldberg and other cases, ${ }^{54}$ the Court fashioned a federal common law of property interests, with attendant procedural rights.

Thus Bishop undermines the entire line of job security cases-indeed, potentially, the entire range of procedural due process cases based on a federally defined property interest-while purporting to be entirely in harmony with these recent precedents. How did the Court come to such a pass? I suggest that the confusion is an outgrowth of a failure of imagination in confronting progressively more problematic claims for security. In the cases following Goldberg the Court has failed to identify the full range of values underlying protection of entitlements and, consequently, has been insufficiently flexible in establishing threshold property interests. Without an adequate threshold, the Court has been caught between an attraction for creating security of interest in largess and a fear of opening the floodgates to limitless claims for costly procedural protections-hence, the confused retreat in Bishop.

I will argue that some of the recent cases, such as Roth, do not

${ }^{32}$ Board of Regents v. Roth, 408 U.S. 564, 577 (1972), quoted in 96 S. Ct. at 2078 n.7.

ss Id. Neither Board of Regents v. Roth, 408 U.S. 564 (1972), nor Perry v. Sindermann, 408 U.S. 593 (1972), contain a single reference to the contract law of Wisconsin or Texas defining agreements terminable at will. In both cases, the Court interpreted the state statutes and regulations without reference to state decisional law. Compare the reliance by the majority in Bishop on Still v. Lance, 279 N.C. 254, 182 S.E.2d 403 (1971), discussed in text at notes 38-42 supra.

st See, e.g., Goss v. Lopez, 419 U.S. 565 (1975), where a majority of the Court held that the Ohio education code created a "legitimate entitlement to a public education as a property interest . . . protected by the Due Process Clause." Id. at 574. But the statute itself afforded absolutely no procedural protection to students, like the plaintiffs, suspended for ten days or less. Goss is discussed in greater detail in text at notes 81-84 infra. 
go far enough in recognizing a property interest in government largess. Such an argument may appear to exacerbate a major source of the confusion in Bishop-a concern on the part of some members of the Court about facilitating a deluge of claims for review of administrative determinations of entitlement..$^{55}$ In fact, I will argue in the next section that the floodgates concern can be alleviated if not entirely dispelled by adjusting our sights downward through a new approach to determining the relationship between threshold entitlements and procedural due process. Initially, however, it is necessary to explore how the excessively rigid methodology for protecting security of interest arose.

\section{Rethinking Entitlement Theory: The Right to an Adequate} Explanation

In Goldberg $v$. Kelly, once the Court determined that the recipient had a property interest in AFDC benefits, it applied its balancing test to resolve the question of what process was due. In succeeding cases this two-stage analysis-establishing the requisite property interest and then detailing the attendant procedural safeguards-was to become a familiar litany. ${ }^{56}$ Indeed, a similar method has been employed in determining the due process safeguards associated with the "liberty" protected by the fourteenth amendment. In Morrissey $v$. Brewer, ${ }^{57}$ involving a parole revocation proceeding, the Court tracked Goldberg in "deciding the minimum requirements of due process":

They include (a) written notice of the claimed violations of parole; (b) disclosure to the parolee of evidence against him; (c) opportunity to be heard in person and to present witnesses and documentary evidence; (d) the right to confront and crossexamine adverse witnesses (unless the hearing officer specifically finds good cause for not allowing confrontation); (e) a "neutral and detached" hearing body such as a traditional parole board, members of which need not be judicial officers or lawyers; and (f) a written statement by the factfinders as to the evidence relied on and reasons for revoking parole. ${ }^{58}$

s5 See quotation from Bishop in text at note 109 infra. This concern is not limited to the right-to-hearing cases. Consider, for example, the Court's increasingly strict construction of the standing to sue requirement-always a litmus test of the Court's posture on the issue of access to the federal judicial forum. See, e.g., Easterm Kentucky Welfare Rights Organization v. Simon, 96 S. Ct. 1917 (1976); Warth v. Seldin, 422 U.S. 490 (1975).

st See, e.g., Mathews v. Eldridge, 424 U.S. 319 (1976); Goss v. Lopez, 419 U.S. 565 (1975).

s7 408 U.S. 471 (1972).

sk Id. at 489 . In subsequent cases assessing the procedural safeguards required to protect 
Shortly thereafter, when the Court decided Roth and Sindermann, it reaffirmed this conceptual approach: the teacher who established a "property" interest was entitled to an opportunity to challenge the sufficiency of the state's case at a hearing, whereas the nontenured teacher had no procedural safeguards whatsoever. ${ }^{59}$

The foundation cases on entitlements, then, developed a bipolar approach. Those with property interests were afforded the full panoply of procedural safeguards employed in an evidentiary hearing, while those who failed to establish a threshold interest were limited to the procedures, if any, established by the state. Despite assertions about case-by-case flexibility, once a property interest was established the inquiry into what process was due developed variations on a single theme: the adjudicatory hearing model.

Indeed, when later cases began to whittle away at Goldberg, they continued to build on the same assumptions about the underlying purposes to be served by procedural due process. In Arnett, for example, the issue was framed in terms of whether a posttermination evidentiary hearing adequately safeguards the entitlement to job security. The debate between the six justices professing allegiance to Goldberg was over the adequacy of evidentiary procedures based on a notice-and-comment hearing model, taken together with a full posttermination evidentiary hearing. Similarly, in the recent case of Mathews $v$. Eldridge, ${ }^{60}$ involving the right to a pretermination evidentiary hearing for recipients of federal disability benefit payments, the Court carefully reviewed the pretermination notice-and-comment provisions providing the recipient with a scaled-down opportunity to present documentary evidence challenging the agency's determination that his disability no longer exists. ${ }^{61}$

the "liberty" interest, the Court has retreated from the full panoply of procedural ingredients provided in Morrissey in a manner that parallels the limitations that have been developed in applying the Goldberg balancing test to property interests. See, e.g., Meachum v. Fano, 96 S. Ct. 2532 (1976); Wolff v. McDonnell, 418 U.S. 539 (1974). See also note 10 supra.

59 In Board of Regents v. Roth, 408 U.S. 564 (1972), the Court stated, "The only question presented to us at this stage in the case is whether the respondent had a constitutional right to a statement of reasons and a hearing on the University's decision not to rehire him for another year." Id. at 569. The district court had held that Roth was entitled to an evidentiary hearing, and the Supreme Court assumed throughout that the issue was whether or not he was entitled to such a hearing. Perry v. Sindermann, 408 U.S. 593 (1972), was presented and decided from a similar perspective. "[P]roof [of a property interest] would obligate college officials to grant a hearing at his request, where he could be informed of the grounds for his nonretention and challenge their sufficiency." Id. at 603.

co 424 U.S. 319 (1976).

"Id. at 334-35. As in Arnett v. Kennedy, 416 U.S. 134 (1974), the claimant was also 
While these recent cases fall short of providing the full inventory of procedural safeguards required by Goldberg, they proceed from the same basic assumption about the relationship between property interests and procedural due process: at a minimum, procedural due process contemplates some kind of a hearing-an opportunity to join issue, through the presentation of evidence to a decision maker who is then obliged to reach a reasoned determination on the basis of the submissions. Underlying this conception is the vital interest in promoting an accurate decision, in assuring that facts have been correctly established and properly characterized in conformity with the applicable legal standard. ${ }^{2}$ When we speak, in administrative law terminology, about controlling administrative discretion or safeguarding against administrative arbitrariness, it is this interest in accuracy that we generally have in mind.

By equating procedural due process with a value that seems to require a right to some kind of a hearing, the Court has correspondingly been driven to set too high a threshold when arriving at an initial determination of whether a property interest exists. In theory, of course, the inquiry into whether a form of government largess creates a property interest can, as the Court and commenta-

entitled to a posttermination evidentiary hearing.

The Court attempted to restate more generally the test to be applied in determining what process is due.

[O]ur prior decisions indicate that identification of the specific dictates of due process generally requires consideration of three distinct factors: first, the private interest that will be affected by the official action; second, the risk of an erroneous deprivation of such interest through the procedures used, and the probable value, if any, of additional or substitute procedural safeguards; and finally, the government's interest, including the function involved and the fiscal and administrative burdens that the additional or substitute procedural requirement would entail.

424 U.S. at 334-35. If the parameters of the statutory entitlement were defined exclusively by the legislative enactment, i.e., without an independent constitutional judgment by the Court, such a "test" of the adequacy of statutory safeguards would presumably be unnecessary. Thus, the majority opinion in a case decided at the same time as Bishop appears to reaffirm the Arnett majority's disavowal of Justice Rehnquist's approach. The case does not, of course, involve a state statutory scheme creating an entitlement. But see note 50 supra.

${ }^{82}$ See generally O'Neil, Of Justice Delayed and Justice Denied: The Welfare Prior Hearing Cases, 1970 Sup. CT. Rev. 161, 184-90. The author discusses a number of values, in addition to accuracy, promoted by an "adversary hearing": accountability, visibility, impartiality, integrity, and consistency. In each case, however, it seems to me that the "value" being promoted is really subsidiary to the interest in assuring an accurate result. Most obviously, impartiality is an important value because of our concern that biased decision makers will either find facts or apply them to the legal standard in a biased-and hence inaccurate-manner. We are concerned about accountability, consistency, and visibility for a similar reason: they serve as a check against the improprieties and mistakes inherent in secret law. See generally K. Davis, ADministrative Law Text 88-122 (3d ed. 1972). 
tors suggest, be neatly separated from the question of "what process is due." 63 In practice, however, whether an entitlement is established or not is determined with an eye to the minimum procedural requirements that would follow as a consequence of a decision in favor of the recipient's claim. A threshold perception of security of interest focuses both on the existence of a "property" interest and the procedural safeguards attendant upon its recognition.

While procedural safeguards linked to some kind of hearing requirement clearly are indispensable to the protection of some property interests or protected activities, such safeguards set too high a threshold for other claims of entitlement. The result, as Roth and Bishop illustrate, is that when the state equivocates about job security, a court cognizant of the high costs of a hearing requirement in terms of administrative efficiency is likely to be reluctant to recognize a property interest. The court then ends up affording no procedural protection at all, even though the employee in such a case may be on a tenure track or even in a "permanent" position. ${ }^{64}$

In what way is a threshold linked to the right to some kind of hearing too high? First, because preoccupation with a hearing has diverted attention from the fact that a significant measure of respect can be afforded the interest in accuracy with a more modest procedural safeguard that does not have the same consequences for administrative efficiency. Second, because excessive attention to the hearing safeguard has concealed the existence of an independent interest-what I will refer to as the interest in an adequate explanation-which has a compelling claim for protection through a more limited due process safeguard. ${ }^{65}$

Fundamental to the concept of procedural due process is the right to a reasoned explanation of government conduct that is contrary to the expectations the government has created by conferring a special status upon an individual. The very essence of arbitrariness is to have one's status redefined by the state without an ade-

43 See, e.g., Mathews v. Eldridge, 424 U.S. 319 (1976); Goss v. Lopez, 419 U.S. 565 (1975); Note, Specifying the Procedures Required by Due Process: Toward Limits on the Use of Interest Balancing, 88 HaRv. L. Rev. 1510 (1975).

"By a tenure track, as distinguished from a "permanent" position, I have in mind a probationary position where there is an expectation that the employee will attain permanent status if his or her performance satisfies established criteria. See the discussion of Roth in text at notes $91-94$ infra.

15 I am not suggesting that a hearing fails to take account of the individual's right to an adequate explanation; on the contrary, the adjudicatory model, even in the modified noticeand-comment form, does provide an explanation of the adverse determination. Rather, I am suggesting: (1) that the independent significance of an adequate explanation is generally overlooked in assessing the need for a hearing; and (2) that the vital interest in an adequate explanation can be protected without resort to a hearing. 
quate explanation of its reasons for doing so ${ }^{66}$ It is crucial that this value be seen as distinct from the concern about administrative accuracy - the interest in correcting wrong decisions. Obviously, the two are related since a reasoned explanation is a means of assuring the individual that the facts in his case are correctly perceived. But I would insist that the respect for individual autonomy that is at the foundation of procedural due process imposes a distinct obligation upon the government to explain fully its adverse status decision. ${ }^{67}$

While such an explanation is surely one of the values promoted by an evidentiary hearing, it is a serious mistake to conclude that the interest in being informed of the rationale for detrimental treatment must stand or fall with the determination of the need for a hearing. Even if one is entitled to no additional procedural safeguards that might promote greater administrative accuracy, one should be protected against a failure of the state to communicate the basis for detrimental treatment. And that protection can be afforded directly through the modest procedural safeguard of a right to a reasoned explanation for the deprivation of an entitlement.

Moreover, such an explanation provides a real measure of support-even if less than would be achieved through a hearing-for the interest in accurate administrative decisions. A decision that must be expressly supported by a detailed statement of reasons is less likely to be taken lightly. A reasons requirement would promote a heightened sense of accountability, an added impulse to investigate thoroughly, and a tendency to clarify analysis (and, in some cases, confront dubious motives).$^{68}$

st The potential damage to the individual's self-regard and sense of psychic security brought on by such an unexplained change in status is one of the central themes in Franz Kafka's great work, The Trial (1925). Kafka creates the chilling ambiance of an unapproachable bureaucratic system that repeatedly issues highly individualized but unexplained and unfathomable decisions that have the most serious personal consequences for the helpless protagonist.

${ }^{67}$ Suppose that a procedure was established whereby a dismissed employee could select a representative with the power to investigate and assure the accuracy of the administrative decision, but that the representative was barred from informing the complainant about anything except the ultimate conclusion whether the agency had acted properly. I would contend that such a refusal to tell the employee why the state had made its decision would countermand an important due process concern, in spite of the assurance of accuracy. See text and notes at notes $81-84$ infra.

ox In this connection, it may be useful to distinguish large and small organizations. The Marion Police Department in Bishop, for example, consisted of only seventeen officers. In such a small organization, a dismissal action frequently embroils the chief official in a personal conflict with the grievant. As a result, it often becomes difficult to sort out proper and improper reasons for the dismissal, making it less likely that the requirement of a reasoned explanation will be honored in good faith rather than in a merely formal sense. In contrast, in a larger police department or other bureaucratic organization the decision to dismiss may 
Procedural due process can be viewed as a layered approach aimed at accomplishing a fundamental objective-protection against arbitrary conduct by the state. One could view the rights to cross-examination, confrontation of adverse witnesses, representation by counsel, decision by an impartial arbiter and so on, as various layers intended to provide increasingly effective insulation from arbitrariness: each layer adds something to the defensive capacity to ward off an arbitrary effort to destroy a status relationship. In some cases-a job security case involving a first amendment claim, for example-the balance struck between the individual values to be protected and the costs of administration weighs so heavily in favor of the individual claimant that a many-layered approach, some form of "evidentiary hearing," seems clearly required. But as we respond to less exigent claims by peeling away the layers of protection-indeed as we strip away any semblance of a "hearing"-it is essential that we retain the core safeguard against arbitrariness, the right to receive a meaningful explanation of what is being done to the individual. ${ }^{89}$

Of course, this right to a meaningful explanation assumes that the individual has some substantive basis for claiming a right to retain the entitlement he possesses. But once we cut loose from the

have to be cleared through a personnel officer or a chief administrator who has no personal dealings with the grievant. In this situation, the requirement of a statement of reasons, backed-as will be indicated-by the threat of limited judicial review, may persuade otherwise indifferent and uninformed personnel officials to make certain that the line supervisor has based his decision on the appropriate standards.

" Apart from an insistence on regard for individual autonomy, the suggested right to a reasoned explanation has nothing to do with what some commentators have called the nonformal aspects of procedural due process-the promotion of values such as political participation, a sense of community, or other relational ends. See Tribe, Structural Due Process, 10 HaRv. C.R.-C.L.L. Rev. 269, 310-14 (1975); and Kirp, Proceduralism and Bureauracy: Due Process in the School Setting, 28 StaN. L. REv. 841, 864-70 (1976), discussing Michelman, Formal and Associational Aims in Procedural Due Process, in Nomos XVIII: Due Process 126 (J. Pennock \& J. Chapman eds. 1977). Without deprecating these goals, I think they frequently are based on a model of an organic community that never had more than limited application to American everyday life.

More importantly, I think fraternal and participational aims are of marginal importance to government job security and many of the other status relationships established by government largess. A termination decision means an end to any existing relationship; hence the individual's principal concern is with his immediate treatment rather than the effect of the state's action on an ongoing relationship. Cf. Handler, Controlling Official Behavior in Welfare Administration, 54 CAL. L. REv. 479 (1966) (arguing that formal legal safeguards are inadequate where the parties are involved in an ongoing relationship and the aggrieved individual is dependent on continuing favorable dispositions by the agency).

Moreover, even if the decision to terminate is overturned, the interest of most public employees, disability recipients, or welfare beneficiaries in some form of fraternal relationship in their continuing dealings with an administrative hierarchy seems speculative and highly attenuated. 
positivist notion that substantive standards are unenforceable where the state has failed to provide procedural safeguards, there is a clear basis for establishing the relationship between entitlements and procedural safeguards. Where a "for cause" standard has been established, as in Bishop, one is entitled, at a minimum, to an adequate explanation of how that standard has been applied. ${ }^{70}$ Moreover, I will argue later that even where no substantive standard has been established by statute or regulation, as in Roth, a non-term position generally implies a right to expect that dismissal will be for reasons relevant to institutional expectations about job performance. ${ }^{71}$ Here too one should be entitled to an adequate explanation of the reasons for termination of employment.

\section{The Right to an Adequate Explanation in Broader Perspective}

Having asserted the importance of the interest in an adequate explanation of adverse action, I want to place it in a broader administrative law framework. There is a curious tendency to view rightto-hearing issues in isolation, as if the questions in these cases about the appropriate degree of deference to administrative discretion were entirely distinctive. ${ }^{72}$ This compartmentalization of the rightto-hearing cases is highly unfortunate. Widening the scope of inquiry, it is possible to identify a general concern about the principle for which I have been arguing-albeit a concern that is ordinarily

70 It should be emphasized that the suggested right to an adequate explanation establishes only a procedural minimum. Whether more extensive safeguards are required is not a question that can be answered by looking abstractly at the nature of the substantive entitlement. Rather, once the entitlement is established, the question of what safeguards are required-what process is due-is determined by balancing the individual security interest against the probable impairment of governmental effectiveness. See Mathews v. Eldridge, 424 U.S. 319, 334-35 (1976), quoted in note 61 supra; Goldberg v. Kelly, 397 U.S. 254, 262-63 (1970), quoted in text at note 14 supra. Thus it does not follow, for example, that because both Bishop v. Wood, 96 S. Ct. 2074 (1976), and Arnett v. Kennedy, 416 U.S. 134 (1974), involved similar substantive "for cause" standards a right to an adequate explanation was all that was required in each case. Proper application of the balancing test might lead to very different conclusions about the appropriate safeguards. For a more detailed discussion of how the balancing test should be applied to various types of substantive interests, see Friendly, supra note 8, at 1278-304; Verkuil, A Study of Informal Adjudication Procedures, 43 U. CH. L. REv. 739, 742-57 (1976); Note, Specifying the Requirements of Due Process: Toward Limits on the Use of Interest Balancing, 88 HaRv. L. Rev. 1510 (1975).

"See discussion in text at notes 91-94 infra. See generally Note, Implied Contract Rights to Job Security, 26 Stan. L. Rev. 335 (1974).

${ }^{72}$ This shortcoming is characteristic of virtually all of the cases discussed herein, from Goldberg v. Kelly, 397 U.S. 254 (1970), to Bishop v. Wood, 96 S. Ct. 2074 (1976). See generally W. Geli.horn \& C. Byse, Administrative Law: Cases and Comments 590-730 (6th ed. 1974). 
expressed in the course of statutory interpretation.

A key case is Dunlop $v$. Bachowski. ${ }^{73}$ Under the LaborManagement Reporting and Disclosure Act of 1959, the Secretary of Labor is required to investigate and, in case of violation of the Act, bring an action against a labor organization that has invalidly certified the results of an intraunion election of officers. Bachowski claimed improprieties in an election for district office in which he was defeated by the incumbent. After exhausting his remedies within the union, he filed a complaint with the Secretary, who refused to file an action on his behalf. No reasons were given for the Secretary's decision; he simply wrote Bachowski a letter stating his conclusion that no action was warranted. ${ }^{74}$ The statute did not specify any procedures the Secretary was to follow in deciding whether to proceed. ${ }^{75}$ Taking an intermediate position between the Secretary's claim of absolute prosecutorial discretion and Bachowski's position-adopted by the court of appeals-that he was entitled to a trial-type hearing, the Court read the statute to require "that the Secretary supply the [union] member with a reasoned statement why he determined not to proceed."76

Bachowski should be viewed as an indirect descendant of the Court's landmark decision in Citizens to Preserve Overton Park $v$. Volpe. ${ }^{77}$ There the Court similarly construed a statute that on its face required a determination, and nothing more, by the Secretary of Transportation that no "feasible and prudent" alternative existed to the use of public parkland in constructing a segment of the interstate highway system. ${ }^{78}$ Refusing to settle for the Secretary's unsubstantiated assurances, the Court insisted that the administrator identify the specific factors that led him to resolve the issue in favor of constructing the highway. ${ }^{79}$

73421 U.S. 560 (1975).

7 The letter said, "Based on the investigative findings, it has been determined . . . that civil action to set aside the challenged election is not warranted." 421 U.S. at 563.

75 The statute simply directed the Secretary to investigate complaints and stipulated that "if he finds probable cause to believe that a violation of this subchapter has occurred and has not been remedied, he shall . . . bring a civil action against the labor organization . . . . 29 U.S.C. $\$ 482$ (1970). It made absolutely no reference to procedures to be followed by the Secretary in determining whether a violation had occurred.

721 U.S. at 572.

7401 U.S. 402 (1971).

${ }^{7 k}$ The statutes so construed in Overton Park were $\S 4(\mathrm{f})$ of the Department of Transportation Act of 1966, 49 U.S.C. $\$ 1653(\mathrm{f})(1970)$, and $\S 18(\mathrm{a})$ of the Federal-Aid Highway Act of 1968,23 U.S.C. $\$ 138$ (1970).

7) Although the statute clearly did not require formal findings, the Court held:

[I]t is necessary to remand this case to the District Court for plenary review of the Secretary's decision. 'That review is to be based on the full administrative record that 
Bachowski and Overton Park turn on principles of statutory construction. Moreover, they are at least partially responsive to a concern for facilitating judicial review. The Court in Bachowski, however, explicitly identified a purpose of its holding to be the assurance of fair treatment for a union member when the statutory scheme creates a special relationship between him and the Secretary of Labor. In fact, the distinctions between these decisions and the security of interest cases may be more apparent than real. The Court's preoccupation with a reasons requirement in Overton Park and later cases $^{80}$ is no less than an acknowledgment that when important interests are at stake, administrative discretion should not go unbridled: at a minimum, fair treatment of competing interests requires that the agency explain in detail why one is to be favored over the other. When the competing interests are those of the state itself and of an individual seeking to maintain a conferred status, I suggest that the threshold commitment to fair treatment, embodied in an explanation of adverse treatment, rises to the level of constitutional significance.

One last precedent, close to home, warrants consideration. Despite repeated references by the Court to a right to a hearing, it is arguably the absence of an adequate explanation that is central to the controversial holding in Goss $v$. Lopez. ${ }^{81}$ The case consolidated a number of actions brought by students who had been suspended from high school for periods of up to ten days under Ohio law, which provided procedural safeguards only in cases of suspensions for a period exceeding ten days. The students, who received only a summary notice of suspension, claimed denial of due process. While the Court referred to the procedural safeguards it imposed as a form of hearing, the requirements are a far cry from earlier efforts to employ an evidentiary model.

There need be no delay between the time "notice" is given and the time of the hearing. In the great majority of cases the disciplinarian may informally discuss the alleged misconduct with the student minutes after it has occurred. We hold only that, in being given an opportunity to explain his version of the facts

was before the Secretary at the time he made his decision. But since the bare record may not disclose the factors that were considered or the Secretary's construction of the evidence it may be necessary for the District Court to require some explanation in order to determine if the Secretary acted within the scope of his authority and if the Secretary's action was justifiable under the applicable standard.

401 U.S. at 420 (footnote omitted).

xo See, e.g., Camp v. Pitts, 411 U.S. 138, 142-43 (1973).

^1 419 U.S. 565 (1975). 
at this discussion, the student first be told what he is accused of doing and what the basis of the accusation is. ${ }^{82}$

At first blush, this procedure may appear to be a farce. Imagine a teacher struck from behind by a flying eraser while writing on the blackboard. In a fury, he storms off to the principal's office demanding that he be supported in his efforts to control the class. Harboring a number of grievances against Jones, a particularly unruly student, the principal instantly concludes that the boy is the culprit. The principal goes to the classroom, shouts at Jones that he is suspended for ten days for striking the teacher with an eraser, and simply ignores the boy's loud protestations to the contrary. Taking the language in Goss literally, Jones has had his "hearing."

But such an analysis of the scenario, while perhaps not implausible, is simplistic. First of all, it assumes no judicial review-an issue to be generally discussed immediately below. ${ }^{83}$ More to the point here, the scenario reveals, by highlighting the occasional arbitrariness of official conduct, what I would regard as the fundamental protection meant to be extended by Goss. Consider the facts of the case. While six of the plaintiffs engaged in disruptive conduct witnessed by the administrator who suspended them, the other three fall into a very different category. One student, Lopez, claimed to be a bystander at a lunchroom disruption that resulted in the suspension of more than twenty-five students. No one testified that Lopez was involved. Another student, Crome, was suspended because she was arrested-again with many others-at a demonstration at another school. Despite the fact that she had been released immediately without charges, she was suspended from her home school. No one testified that Crome was involved in the incident. As to the third student, Smith, the school files gave no reason for his suspension, let alone supporting testimony for its basis. What these students were not given, and what I regard as fundamental to the holding, was an explanation of how the administration identified them as troublemakers warranting suspension. The arbitrariness resided in substituting an edict for an explanation. ${ }^{84}$

"2 Id. at 582 .

${ }^{k 3}$ See text at section $\mathrm{V}$ infra. In the context of the preceding scenario, consider whether a limited nonfactual standard of review would be feasible in cases arising under the informal notice-and-comment standard of Goss v. Lopez, 419 U.S. 565 (1975). If the right to respond is to be meaningful, would it not be necessary to allow testimonial evidence on whether the administrator took account of the response? In order to avoid the parody of an informal notice-and-comment proceeding exemplified in my hypothetical, might the courts be impelled to require in the first instance more of a formal evidentiary-type hearing than the Goss majority anticipated?

*: While I regard the absence of an adequate explanation as central to the majority view, 


\section{The Right to an Adequate Explanation and the Role of JUDICIAL REVIEW}

If the requirement of a rational explanation is to have meaning it must be based on more than an unenforceable obligation to supply reasons. Without some form of judicial review, the individual would remain vulnerable to irrevocable changes in status unsupported by an adequate explanation since the reasons requirement could be ignored with impunity. The principal benefit of judicial review in this context is its likely deterrent effect on arbitrary conduct. If the reasons given for a termination decision are subject to review, the agency's decision is more likely to be taken with greater deliberation and probity in the first instance. The chance of a good faith erroneous decision-based on insufficiently verified hearsay, for example-is lessened, and the chance of conscious official misconduct is also diminished.

Yet a judicial commitment to monitor the basis in fact for an administrative statement of reasons would quickly bring us to the brink of imposing some form of adjudicative hearing requirement, either in the administrative or judicial forum or in both. Thus, the key question is whether judicial review of the threshold due process safeguard can be afforded that is both meaningful and procedurally modest. I suggest that such review is possible along the lines that

the informal notice-and-comment procedure invoked in Goss is both broader and narrower than my proposed right to a detailed statement of reasons. It is broader in that the Court did insist upon an opportunity to respond. Such an opportunity appears to have been imposed as an additional safeguard of accuracy:

Requiring that there be at least an informal give-and-take between student and disciplinarian, preferably prior to the suspension, will add little to the factfinding function where the disciplinarian has himself witnessed the conduct forming the basis for the charge. But things are not always as they seem to be, and the student will at least have the opportunity to characterize his conduct and put it in what he deems the proper context.

419 U.S. at 584.

On the other hand, the explanation required to satisfy the "informal give-and-take" standard is probably less demanding than my proposal. As such, it both diminishes the impetus towards greater accuracy created by the requirement of an opportunity to reply, and is less responsive than my proposal to the independent interest in a clearly articulated rationale for the decision.

Like my proposed requirement of adequate reasons, the informal notice-and-comment standard imposed in Goss can be viewed as a departure from the adjudicatory model of procedural due process. Realistically, I would suggest, the cases, beginning with Arnett v. Kennedy, 416 U.S. 134 (1974), that impose modified hearing provisions-and finally, in Goss, a nonhearing safeguard-can be viewed as various options on a continuum, with my proposed right to an adequate explanation at one extreme and the adjudicatory model employed in Goldberg v. Kelly, 397 U.S. 254 (1970), and Morrissey v. Brewer, 408 U.S. 471 (1972), at the other. 
are spelled out in Dunlop v. Bachowski. ${ }^{85}$ After cataloging its bases for a "reasons requirement," and emphasizing the necessity that the judiciary avoid substituting judgment for the administrator, the Court elaborated on the scope of review anticipated.

Except in what must be the rare case, the [district] court's review should be confined to examination of the reasons statement, and the determination whether the statement, without more, evinces that the Secretary's decision is so irrational as to constitute the decision arbitrary and capricious. Thus, review may not extend to cognizance or trial of a complaining member's challenges to the factual bases for the Secretary's conclusion either that no violation occurred or that they did not affect the outcome of the election .... "If . . . the Court concludes . . . there is a rational and defensible basis [stated in the reasons statement] for [the Secretary's] determination, then that should be an end of this matter . . ." [citing a prior district court case]. ${ }^{86}$

The Court continued by disavowing an intention to require "detailed findings of fact," but warned that the union member must be informed of "both the grounds of decision and the essential facts upon which the Secretary's inferences are based." 87 In fact, the district court had ordered the Secretary to furnish such a statement prior to the handing down of the Supreme Court's decision-it is attached as an appendix to the opinion in Bachowski. In it, the Secretary provides a twelve-page statement that clearly shows how he determined on a union local-by-local basis that even under the most favorable inferences to Bachowski the maximum number of votes changed in the district would not have resulted in his election. It was just such a statement, the Court argued, that should have been provided in the first instance. ${ }^{88}$

I suggest a similarly limited standard of judicial review, providing an aggrieved individual with a judicial remedy when the agency fails to supply an explanation for its decision that indicates clearly and in detail why the adverse determination has been reached. It can be argued that an obligation of such limited scope would fail to protect adequately against the possibility of arbitrary treatment.

${ }^{* 5} 421$ U.S. 560 (1975).

s. Id. at $572-73$.

87 Id. at 574 .

** The Court, however, expressed no final judgment about whether the statement was in fact adequate. That determination was left to the district court on remand. Id. at 577 . 
Instead of receiving no explanation for the adverse decision, the grievant might be supplied with an explanation that, beneath a formal appearance of responsive treatment, is in fact totally false. Thus, with only limited judicial review available, a strong temptation might exist to terminate relations with a disagreeable employee by issuing a pro forma recitation of misconduct, whatever the substance of the case against him.

This argument overlooks a number of factors. The formality of having to provide a detailed written statement of reasons is itself likely to deter some, although admittedly not all, bad faith dealings. To put it directly, many administrators would be uneasy about the consequences of committing themselves in writing to a trumped-up rationale for decision, if only because of the possibility of adverse publicity. In addition, in any sizeable bureaucracy there are likely to be internal controls, such as a requirement of clearance with disinterested higher level officials, that would be substantially reinforced by the deterrent effect of potential limited judicial review. ${ }^{89}$ Finally, there are almost certainly a substantial number of instances where erroneous termination decisions result solely from indifference or slipshod procedures, rather than bad faith. The threat of judicial review, even review limited in scope, is likely to have a salutary effect in such cases.

Thus, I would argue that when reasonably held expectations-arising out of everyday understandings as well as official rules and regulations-establish a threshold security of interest, the holder is entitled to a detailed statement of reasons for the termination of that interest, backed by the assurance of limited judicial review of the adequacy of the administrative explanation. ${ }^{90}$ Now I

see note 68 supra.

" Again, I should emphasize what I hope is apparent about my purposes. My primary aim is to articulate a broader-and, as the next section will argue, a more realistic-view of when an employee's interest in maintaining his position ripens into an entitlement. But in arguing for the necessity of recognizing minimal due process requirements, I do not mean to suggest the sufficiency of such safeguards in all cases. See note 70 supra. Sensibly applied, the balancing approach of Goldberg $v$. Kelly seems essentially correct: some values, whether free speech or minimum economic sustenance, do in fact require greater protection than others. Similarly, some kinds of status determinations, e.g., misconduct inquiries, typically involve disputes over whether certain facts occurred while others do not; this likelihood of disputed issues of fact weighs strongly in favor of requiring adjudicatory procedures. Consequently, it should be possible to establish an array of claims for largess entitled to varying degrees of procedural protection. See text following note 68 supra; authorities cited in note 70 supra. I accept the notion of a continuum of interests and argue only that a lower threshold should be recognized for purposes of providing the minimum protection. Because job security cases, particularly Roth and now Bishop, have been treated as falling below the existing entitlement threshold, they serve as an ideal vehicle for propounding my thesis. 
must demonstrate more concretely, with special reference to the question of job security, where the threshold is to be established and how the procedure is to be implemented. To do so, I return to Bishop and the related cases from a fresh perspective.

\section{The Right to an Adequate Explanation: Reassessing the Job SECURITY CASES}

The irony of the Bishop case is that the Marion ordinance, given a sympathetic construction, can be read to provide as a matter of positive state law what I am suggesting should be a minimum constitutional protection for status relationships-the right to a statement of reasons. The trial court, however, adopted the bipolar approach to job security cases taken in Roth and Sindermann: one either has a sufficiently weighty interest to require the protection of an evidentiary hearing or has no interest worth safeguarding at all. The same theme resounds throughout the majority opinion in the Supreme Court, although the deference to state law seems to turn the issue on its head: if the state intended to create a "property" interest in the job, Bishop would have been given some form of statutory tenure with attendant procedural safeguards.

Roth encouraged a bipolar approach-but not deference to state law-both by posing the constitutional issue as evidentiary hearing vel non ${ }^{91}$ and, correlatively, by suggesting an inordinately sharp distinction between the expectations of tenured and nontenured college teachers. This was an unfortunate step. While it is surely true that nontenured professors have expectations different from those of their tenured colleagues about the level of competence

A related limitation of scope needs to be made explicit. There is no magic to existing status relationships, in job retention or otherwise, as a base line for defining entitlements. It could be argued that in some cases the job or license applicant has a reasonable expectation of fair treatment that is sufficient to trigger a minimal entitlement to an adequate explanation for adverse treatment. Again, however, the case for recognizing that applicants have "property" rights simply underscores the fact that some claims for fair treatment are more substantial than others-and there does seem to be special urgency to the claim of one who has established an interest in largess which government is seeking to terminate. For present purposes, I cannot go beyond suggesting what I regard as a more adequate framework for analyzing these claims in the context of a single illustration, the case of job retention.

Finally, in arguing the salience of judicial review I assume the continuing existence of a cause of action such as the present one based on the Civil Rights Act, 42 U.S.C. § 1983 (1970), discussed in note 18 supra, and 28 U.S.C. $\$ 1343$ (1970), the companion jurisdictional provision. The courts have not had to decide whether due process requires judicial review in the absence of a statutory basis, and I similarly want to avoid that perplexing issue here. See generally Rabin, Preclusion of Judicial Review in the Processing of Claims for Veterans' Benefits: A Preliminary Analysis, 27 Stan. L. Rev. 905, 907-11 (1975).

"See note 59 supra. 
that will insure retention, it is most emphatically not true that they contemplate dismissal "for no reason at all." Rather, a nontenured teacher anticipates dismissal for any reason related to institutional academic expectations, including economic feasibility. This relevance standard is very broad, and certainly legitimates considerations of personal compatibility and projections of future productivity; it is a standard that within wide parameters should be set by the employing institution. But it does not incorporate dismissal for reasons unrelated to the job, such as distinctive modes of private behavior, or termination for reasons that turn out to be based on misinformation. A tenure track professor does have minimal expectations of security, grounded in reliance that the institution will engage in an honest inquiry and employ job-related criteria in reassessing his or her status. ${ }^{22}$

There is no particular reason to limit this line of argument to the academic sphere. Assuming continued economic feasibility, a tenure track position - that is, one leading to "permanent" employment $t^{93}$-is generally understood to imply a good faith commitment not to terminate an employee unless it has been ascertained that the employee is unsuited to the position. ${ }^{94}$ Term agreements, which trigger no such expectations, are easily enough established by express notice or contract-although, I would insist, these provisions should be interpreted with reference to federal constitutional standards. Bishop then becomes a clear case: the employee was a regular officer on the police force who had attained an explicitly provided permanent classification and was actually protected by a "for cause" standard. To hold that he had no security of interest, and indeed would have had no greater entitlement if he had been on the force for thirty years, is a mockery of the notion of property interests in government largess. ${ }^{95}$

92 These expectations are, of course, entirely apart from the guarantees afforded to constitutionally protected activity; the infringement of such activity is generally understood to trigger the right to an evidentiary hearing in some forum. See note 19 supra.

see note 64 supra.

s) There is no particular reason to limit this line of argument to job security. It is central to the notion of due process that whenever government takes action which invests an individual with personal largess, whether a driver's license or disability benefits, there is an implicit commitment that the relationship will be terminated only for reasons relevant to the existing status.

${ }^{95}$ One could argue that job security is simply not sufficiently important, when compared with other kinds of interests-for example, child support benefits or minimally decent housing-to warrant protection as an entitlement apart from whatever protection the state affords. See Grey, supra note 27. Again, I would regard the importance, or "moral claim," of a particular interest as principally relevant to the second-stage balancing test used in determining the applicable procedural safeguards. I do, however, recognize that at some point a 
The Bishop majority, by treating the employee as entitled to no more than he received and polarizing the Court by insisting on the primacy of state law, missed the opportunity modestly to effectuate the broader purposes of procedural due process. ${ }^{96}$ Bishop's security of interest was surely weightier than Roth's yet I argue only that Bishop, like Roth, should have been given an adequate explanation for his dismissal. ${ }^{97}$ It may well be that the costs of adjudicatory procedures in a police department, or other agency with a high turnover rate, would be considerable. It may also be true that the bureaucratization entailed by such procedures would be harmful to agency morale, either because of the delay engendered in effecting the dismissal of troublemakers or because of the greater reluctance to trigger an enervating process. But it does not follow that the more limited commitment to fair dealing that I propose would entail these costs. ${ }^{98}$

Furthermore, judicial review can be effective without being elaborate by limiting its scope to a review of the reasons statement. A brief examination of the record in Bishop indicates the operational consequences of the standard of review I am suggesting in threshold entitlement cases. The defendants' motion for summary judgment was supported almost exclusively by a highly conclusory and ambiguous affidavit from Chief of Police Wood. ${ }^{99}$ In his statement Wood charged that:

threshold definition of property interests will exclude claims for due process protection: to put an absurdly easy case, the individual who is summarily "dismissed" over the phone in his request that the Park Service provide him with weather information at Yosemite National Park. See also note 90 supra. In defining that threshold, I agree that one must take account of the substance of the moral claim.

" Compare the contemporaneous treatment of the liberty interest in Meachum v. Fano, 96 S. Ct. 2532 (1976).

"It does not necessarily follow that the discharged employee in Arnett v. Kennedy, 416 U.S. 134 (1974), was similarly entitled only to an adequate explanation. Indeed, it may be that the police force, charged with maintaining public security, which frequently involves team efforts under dangerous conditions, is sufficiently unlike the academic setting in Roth that a different set of procedural safeguards is called for in these two circumstances. See notes 70 \& 90 supra.

2x To the contrary, it seems improbable that an obligation to provide a detailed explanation of termination decisions would cause a marked increase in administrative expense. Presumably, a conscientious bureau chief would have taken the time and effort to insure that his termination decision had an adequate basis in fact anyway; thus, the added burden imposed by a reasons requirement is merely a matter of providing documentation. It is equally unlikely that the requirement of documentation, without the delays in effecting removal caused by a hearing, would have any discernible negative impact on agency morale.

"It is essential to keep in mind that the testimony, discussed in text and notes at notes 100-06 infra was offered in the district court to support cross-motions for summary judgment on the right to a hearing. At the time of his dismissal, Bishop received "notice" as nominally 
I had [Bishop] in my office on several occasions during a six month period prior to his discharge, concerning high speed auto chases outside the city limits, checking business establishments in the city and answering patrol calls.

. . . Bishop did not attend training sessions . . . refused to cooperate with fellow officers and did not take orders from the officer in charge of his duty shift. Officer Bishop was the cause of low morale ... and a verbal complaint was filed against him by Sergeant Arrowood . . . .100

Despite the wide variety of charges, Wood's affidavit was virtually unsubstantiated. The sole supporting statement was one other officer's summary comment that "Bishop's attitude was to the effect that he though he was the only man who did anything." 101 Neither Sergeant Arrowood nor any other member of the department testified to Bishop's harmful effect on the morale of the police force or his personal misconduct. ${ }^{102}$ Moreover, many of the charges are highly ambiguous; what, for example, is one to make of the unexplained need to talk to Bishop about "checking business establishments in the city and answering routine patrol calls." In his sworn statement Bishop suggested that he was fired, if anything, for performing these tasks too conscientiously. ${ }^{103}$ In addition, he provided supporting affidavits from two fellow officers on the force who testified that Bishop was a model policeman, highly efficient, well liked and respected by his peers. ${ }^{104}$ Arrest records for the period Bishop

required under the Marion ordinance, but it appears from the trial record that the written document consisted of nothing more than a summary statement that his work was unsatisfactory and that he missed training sessions. This surmise was confirmed by a telephone interview with Bishop's attorney, Norman B. Smith, Greensboro, N.C., on Oct. 14, 1976. As the following textual discussion indicates, an adequate statement of reasons would have required a more precise and detailed explanation of the Chief's decision than was provided in his affidavit.

${ }_{100}$ Affidavit for Respondents, Bishop v. Wood, 377 F. Supp. 501 (W.D.N.C. 1973).

101 Affidavit for Respondents, Bishop v. Wood, 377 F. Supp. 501 (W.D.N.C. 1973).

102 The record indicates that Sgt. Arrowood was still on the force when Bishop was decided below. See Answers to Petitioner's Interrogatory, Bishop v. Wood, 377 F. Supp. 501 (W.D.N.C. 1973).

${ }^{103}$ In his complaint, Bishop alleged that he was dismissed because "he treated the citizens of his community equally without regard to their political or social status." The only charges with any degree of specificity are those regarding high speed auto chases and missed training sessions. Bishop testified that officers generally were engaged in the former practice until told otherwise by the Chief and that he had complied as of that date. He gave plausible explanations for each training session that he missed-in one case offering supporting affidavits from two state police officers he had assisted in an emergency while he was on the way to a session.

104 Both of these officers testified for Bishop, see Affidavits for Petitioner, Bishop v. Wood, 377 F. Supp. 501 (W.D.N.C. 1973), despite their continued service on the force at the time of the litigation. 
was on the force established that he made more arrests, by far, than any other member of the Marion Police Department. ${ }^{105}$

A picture emerges of an officer who may have been fired for overzealousness-more darkly, as Bishop suggested, for failure to recognize certain class distinctions in enforcing the law. ${ }^{108}$ This is pure speculation, of course; Bishop may have been fired for the best or worst of reasons. What is clear is that the City Manager and the Police Department failed to provide a reasoned basis for Bishop's removal at the time of his dismissal. As a result, he was arbitrarily dismissed. ${ }^{107}$ In the absence of an adequate statement of reasons, the court should have either granted summary judgment for the plaintiff or remanded for a further explanation of the decision.

I have subjected the Bishop case to rather close scrutiny because it is essential to establish the feasibility of requiring a statement of reasons. In view of what appears in the record, how might this obligation have been discharged? If Chief Wood had provided a statement of reasons that recited specific shortcomings in Bishop's performance of his duties, such as a brief summary of the alleged "verbal complaint" of Sergeant Arrowood, or an explication of Bishop's shortcomings in responding to patrol calls, then defendants would have been entitled to summary judgment. As the Court said in Bachowski, "except in what must be the rare case, the court's review should be confined to examination of the reasons statement." 108 The judiciary need not sit in review of substantial honest. conflicts in the testimony. If Chief Wood had provided a cogent statement indicating that Bishop's personality was in fact creating real morale problems, defendants would similarly have been entitled to summary judgment, since a substantial degree of judicial deference is warranted in determining the scope of relevant job characteristics. In sum, my analysis of Bishop is meant to illustrate

105 Indeed, with the exception of one other officer who was well behind him, Bishop made more arrests than any three members of the force combined. Affidavit for Petitioner, Bishop v. Wood, 377 F. Supp. 501 (W.D.N.C. 1973).

10s See note 103 supra.

${ }^{107}$ See note 99 supra.

${ }_{10 x} 421$ U.S. at 572. The Court listed as examples of such a "rare case" the complete abrogation by the Secretary of his enforcement responsibilities, the prosecution of complaints in a constitutionally discriminatory manner, and decisions "plainly beyond the bounds of the Act [or] clearly defiant of the Act." Id. at 574. Bachowski is silent, however, as to whether substantial conflicts in written testimony-such as occur in Bishop- require oral evidentiary testimony. If they do, then the door is open for review of the truthfulness of the grounds for the decision. While there is a very real attraction to judicial enforcement that would test the truth of the reasons given for dismissal, the cost would be too high-especially in view of the important functions served by the modest requirement of a reasons statement per se. See text following note 88 supra. 
two propositions about the minimum requirement of an adequate explanation: first, that the requirement would not transform the judiciary into a superagency reviewing a multitude of claims, and second, that those cases which do, in fact, transgress the standard generally would not be particularly difficult to identify.

Viewing the floodgates with trepidation, the majority in Bishop asserted that

[t] he federal court is not the appropriate forum in which to review the multitude of personnel decisions that are made daily by public agencies. We must accept the harsh fact that numerous individual mistakes are inevitable in the day-to-day administration of our affairs. The United States Constitution cannot feasibly be construed to require federal judicial review for every such error. ${ }^{109}$

This tough-mindedness is misplaced. The federal courts will not be overwhelmed by a "multitude of personnel decisions" if the Court adopts a threshold definition of security of interest that recognizes the importance of an adequate explanation for adverse status determinations and links that recognition to an appropriately modest form of judicial scrutiny.

In any event, it is whistling in the dark to think that redefining procedural protection of property interests to be a matter of state law will somehow make the job security cases go away. A considerable number of teacher tenure cases involve separate claims of infringement of a federally protected constitutional interest-witness Roth and Sindermann ${ }^{110}$ - in which case it remains clear that federal judicial review and an evidentiary hearing are available. ${ }^{111}$ Dis-

109 96 S. Ct. at 2080.

1t In Board of Regents v. Roth, 408 U.S. 564 (1972), for example, the plaintiff had publicly criticized the administration for suspending an entire group of 94 black students without determining individual guilt. He also criticized the university's regime as being authoritarian and autocratic. He used his classroom to discuss what was being done about the black episode; and one day, instead of meeting his class, he went to the meeting of the Board of Regents.

Id. at 579-80 (Douglas, J., dissenting). In Perry v. Sindermann, 408 U.S. 593 (1972), the plaintiff was president of the teachers' union at the state college where he taught. In that capacity, he was engaged in a running controversy with the administration over its policies; he had also cancelled a number of classes to testify before the state legislature. He alleged that his dismissal was based on his criticism of the college administration.

i' Apart from cases of professional incompetence, in which considerable deference would continue to be afforded to the institutional statement of reasons, most academic dismissal cases involve a faculty member protesting some aspect of administration policy. Whether the controversy is over hiring practices, investment decisions, minority admissions, or a wide variety of other issues of academic governance, a first amendment claim to protection can generally be made. 
missal cases in every sphere of public sector activity are likely to yield a fair share of such claims. ${ }^{112}$ More importantly, even if the federal case load could be alleviated by abandoning the effort to define property interests from an independent constitutional perspective, the interest of the individual in maintaining a base line of protection against the indifference of a bureaucratic state should not be sacrificed to other meritorious claims on judicial resources.

Moreover, consider again the facts of Still v. Lance, 279 N.C. 254, 182 S.E.2d 403 (1971). There, it will be recalled, the plaintiff claimed sex discrimination in the failure to rehire her because of her husband's dismissal. Presumably, the federal courts would be available for adjudication of such a claim, or a claim of race discrimination, under Title VII of the Civil Rights Act. See Civil Rights Act of 1964, tit. VII, 42 U.S.C. $\$ \S 2000$ e to $2000 \mathrm{e}-17$ (1970).

112 See Civil Rights Act of 1964 , tit. VII, 42 U.S.C. $\$ \S 2000$ e to 2000 e-17 (1970). In cases of race or sex discrimination public employers excluded from the provisions of Title VII because of their size or intrastate activities could presumably still be sued in federal court under 42 U.S.C. $\S 1983$ (1970), by alleging a denial of rights protected by the equal protection clause of the fourteenth amendment. Nor are potential claims for first amendment protection limited in any way to the teaching profession. In fact, the employee in Arnett v. Kennedy, 416 U.S. 134 (1974), claimed a free speech interest in criticizing the manner in which his superior-the chief of the regional office of OEO-was performing his job. 